\title{
SHATTERING TRADITION: A REJECTION OF ANALYSIS BY GENRE IN HORACE'S ARS POETICA ${ }^{1}$
}

\author{
H G D Williams (University of Cape Town)
}

\begin{abstract}
The following paper undertakes a critical review and examination of the various attempts over the last century and a half of scholarship in Classical Philology to categorize that most singular work of Horace, the Ars poetica. Commentators and critics of the poem have endeavoured to include the work of the Augustan poet within various pre-determined - somewhat tendentious - generic categories, including: the didactic treatise, the verse letter, the literary epistle, the didactic poem, and the sermo. Through critiquing these approaches I shall argue that the Ars, whether through form or subject, manages to subvert the criteria of these generic boundaries, and locates itself within a unique territory. Apart from addressing the problems involved in classifying the Ars, this paper also tackles some other general concerns of generic analysis in Classical Philology.
\end{abstract}

In the following paper I shall explore and criticize various scholarly attempts to classify the genre of that most eclectic and farraginous work of Horace, the Ars poetica. This paper must, accordingly, be pardoned for being essentially destructive in nature: but I believe that it will only be possible for critical analyses of the poem to advance once we have cast ourselves free of the excess baggage - that is, generic expectations - which is frequently prescribed for our comprehension of this most singular composition in the Horatian oeuvre.

As a starting point, the very name, the 'Ars poetica', should suggest to us a type of philosophical or didactic prose treatise. The problem, of course, is that we do not know whether this was the title which Horace himself gave to his poem; indeed, we do not even know whether Horace had in fact created a definitive title for publication (Rudd 1989:19). Quintilian, in the following century, bestowed the titles of 'Ars poetica' and 'Liber de arte poetica' upon the poem. ${ }^{2}$ Wilkins

1 The financial assistance of the National Research Foundation (NRF) and the University of Cape Town towards this research is hereby acknowledged. Opinions expressed and conclusions arrived at, are those of the author and not necessarily to be attributed to them. Moreover, I would like to thank Associate Professor Clive Chandler of UCT for his guidance and assistance throughout my MA, of which this paper is a result.

2 'Originally the work may have been called Epistula ad Pisones; certainly its status as an epistle is implied by the grammarian Charisius (fourth century AD) who cites the work by the phrase Horatius in Epistularum. But Quintilian (first century AD) referred to it as the ars poetica (Pref. to Trypho, 2) and as the liber de arte poetica (8.3.60), and the first 
acknowledges the artificiality of these titles and rightly supposes that they might consequently mislead us into a certain predefined approach towards the poem (Wilkins 1886:333). To put it simply, if we read a poem entitled 'On the art of poetry', we will automatically read it as a didactic treatise. Consider how different the historical reception of Horace's poem would have been, had it been unanimously titled 'Epistula ad Pisones', as it is in some modern editions, such as Rudd's.

I should add here that there is always a danger for the literary critic of amalgamating the reception of a literary work into our analysis of the work itself. ${ }^{3}$

Certainly, it is true that Horace's works in general served an important didactic function in the school curriculum; ${ }^{4}$ however, such a didactic reception, as perhaps reflected in the posthumously-fabricated title 'Ars poetica', need not denote that the work itself was crafted by Horace as a didactic treatise. We might, by the same anachronistic approach to literature, entitle Virgil's Aeneid a 'didactic' treatise, simply on account of the fact that it played so important a role in the educational syllabus in antiquity.

To return to the subject of genre, it is quite useful, as most critics have tended to do when considering how to classify the Ars poetica, to commence our analysis by reflecting on what kind of epistle the work is: how it positions itself among Horace's other letters and, indeed, how it fits into the tradition of letterwriting.

It has long been realised that Horace's three longer epistles (to Augustus, Florus, and the Pisones) - often amalgamated, probably anachronistically, ${ }^{5}$ into a single book called 'Epistles 2' in many modern editions — present a wholly different tone to those of his first. The initial twenty shorter letters often maintain a familiar tone with their addressees, while the relationship between the "Horace' ${ }^{6}$ of

of these titles has stuck' (Rudd 1989:19). Indeed, the fact that Quintilian refers to it as a liber does imply that the Ars was regarded as a free-standing entity by that time, removed from all the other epistles.

3 In other words, what has been generally termed in literary theory 'The affective fallacy', after the essay of the same name by Wimsatt and Beardsley; so, for example, the modern English student often tends to 'read himself' according to Shakespeare, Milton, et cetera, far removed from the original context (Wimsatt \& Beardsley 1972:351).

4 'Horace retained his standing as a school author throughout late antiquity, and it is not surprising to find him frequently evoked by the major Latin poets of the period, such as Claudian and Ausonius' (Tarrant 2007:281-282)

5 For further discussion on the placement of the Ars, see Brink 1971:12-21.

6 In inverted commas so as to distinguish the authorial persona from the historical personage known as Horace. 
'Epistles 2' and his recipients is far less 'intimate', far less involved (Ferri 2007: 130-131). ${ }^{7}$

Moreover, even when focusing solely on the three longer epistles, the attachment of the $A r s^{8}$ to its addressees seems feeble, bearing little effect on the composition of the work, compared to the other two letters.

To illustrate this point, we might, without any obvious alteration to the effect or function of the poem, remove the names of the 'Pisones' from the Ars and replace them with any other familiar Roman cognomen; on the other hand, substituting the title of Augustus, Caesar (Hor. Epist. 2.1.4), from the first epistle of the second book would radically alter our appreciation of that work. He has been fully integrated into the text as an addressee with his own set of preoccupations and expectations: 'Thus we find that the addressees in these poems [to Florus and Augustus] are so precise and, it appears, so controlling of the sort of material to be discussed that the ever-present generalized addressee of didactic poetry ${ }^{9}$ vanishes. Epistles 2.1 and 2.2, furthermore, rather than aiming to teach Augustus or Florus anything of significance, function primarily as apologies' (Toohey 1996:149). Indeed, even if we were to have more information on just who the Pisones were, I think it is doubtful whether this would greatly enhance our critical readings of the Ars.

Having said that, it must be admitted that there is little concord among critics about the relative importance of the Pisones to the poem, whether they are really just 'dummy figures', to use Katharina Volk's terminology, through which an imagined audience is communicated to, or whether their preoccupations do shape the poem (Volk 2002:38).

Some critics, such as Joan Plotnick, point to the obscure reference to Roman satyr plays (or the dramatic focus in general) at the centre of the Ars as being directed towards the interests of the addressees (Plotnick 1979:329-335); while others, such as David Armstrong, have conjectured that the Pisones invoked in the poem were supporters and patrons of Philodemus and that the Ars constantly maintains a style and content reflective of the mores of this Epicurean philosopher (Armstrong 1993:185-230). ${ }^{10}$ Nevertheless, I should think that the distance which the Ars maintains from its generalized addressees - as contrasted with the more 'integrated' addressees in Horace's other epistles - might encourage us to locate the work within the tradition of Greek didactic epistles, such as those of the

7 See note 13, and page 4, last paragraph, for further discussion.

8 Which I shall henceforth use as an abbreviation for the Ars poetica in this essay.

9 Which I discuss as a potential genre for the Ars below, after I have introduced the problem of integrating the hexameter verse with the epistolary form.

10 In a similar vein of thinking, WS Anderson attempts to locate a Socratic 'Horace' 'Socratic style' and 'Socratic content' — in the first four sermones of Satires 1. 
philosopher Epicurus, where the names of Herodotus or Menoeceus play a minimal, if any, role in the philosophical exposition of the Epicurean system. I am certainly in agreement with Russell as to the relative importance of the historical Pisones to the poem, when he declares succinctly: 'It is very much a treatise with dear so-and-so at the beginning' (Russell 1973:113).

This characterization of the Ars poetica as a technical didactic treatise where the epistolary form is a mere convention which only pays lip service to the true historical addressees, who are in effect dummy figures, conduits through whom an imagined audience is lectured, has indeed been a popular interpretative stance: '[m]uch labour was spent in this century and the last tracing the alleged derivation of the Ars poetica from the genre of the technical handbook' (Frischer 1991:87). However, such a critical response does ignore the second fundamental difficulty in designating a genre: that is to say, how do we account for the hexameter verse? The type of technical treatise in epistolary form - we might say in more modern terms, the genre of the 'letter thesis' or 'letter essay' — within which Epicurus, for example, wrote, was of course presented in standard prose, not poetic metre. ${ }^{11}$

Bernard Frischer, in his work Shifting paradigms: New approaches to Horace's Ars poetica, has argued persuasively that there are three ways in which we can resolve the epistolary form with the poetic: '[o]nce we see that the Ars is most likely an independent work in the corpus, three possible ways of classifying it as something other than a handbook come to mind, of which the second two have rarely, if ever, been raised in this century: a verse letter, a didactic poem, or some tertium quid'12 (Frischer 1991:89). Let us then briefly discuss the potential placement of the Ars poetica within each of these genres, as Frischer outlines.

The verse letter, of which Horace's first book of epistles is a prime example, ${ }^{13}$ is, according to Frischer, defined by a tone which is 'informal in spirit and supplies or requests information of some sort from or to a friend' (Frischer 1991:89); regarding the second criterion, he provides the following definitions by Ps.-Acro and Porphyrio: epistulis enim ad absentes loquimur, sermones cum praesentibus $^{14}$ (Ps-Acro Commen. In Horatium Sat. 1.1.1), and in sermonum autem libris vult intellegi, quasi apud praesentem se loqui, epistolas vero quasi ad

11 For further refutation of the notion of the Ars as a technical treatise, see Frischer 1991:88, note 3, in which he argues that the classification of the Ars under such a heading is largely an anachronistic result of the epistle theses of the sixteenth century.

12 That is to say, the genre of the sermo, discussed further below.

13 Frischer tracks the development of the genre of the verse letter in Roman literature to Spurius Mummius in 146 BC (Frischer 1991:90, note 8).

14 'For in epistulae we talk to those who are absent, while we address sermones to those who are present'. Unless otherwise stated, all translations are my own. 
absentes missas ${ }^{15}$ (Porphyrio Commen. In Horatium: Sermonum Liber Primus 1.1). It is quite clear in reading the Ars poetica, I believe, that there is no exchange of information, none of the reciprocal discourse which one finds in a verse letter, addressed to an absent friend; ${ }^{16}$ rather, the Pisones appear to be addressed in the poem as though they were present, 'quasi apud praesentem'. ${ }^{17}$ As I discussed above, they seem to be the typical generalized addressees of didactic discourse.

There are, moreover, some other formal conventions of the typical verse letter which are conspicuously absent in the Ars. Firstly, the addressees, the Pisones, are not referred to until the sixth line of the poem: 'In all but one of Horace's poems that are indisputably epistles, the addressee is named, or referred to by some form of $t u$ or a verb in the second person singular, in the first sentence and usually the very first line. The Ars poetica does not begin in this typically epistolary way' (Frischer 1991:92); the Ars, however, commences in an uncommonly generalized fashion for a verse epistle, a most impersonal discussion on the nature of artistic representation. Secondly, the Ars must be distinguished from other Horatian verse epistles in having multiple addressees, 'father and sons, worthy of their father' ${ }^{18}$ (Frischer 1991:92). A third formal element, quite evident but easily overlooked, is the sheer size of the Ars poetica: at 476 lines it is roughly nine and a half times ${ }^{19}$ longer than the average ${ }^{20}$ epistle from Horace's first book, and just over 200 lines longer than the largest verse epistle, to Augustus (Toohey 1996:149). Given how radically the Ars poetica differs from the verse epistle in its formal structure and in the manner in which it treats its addressees, serious doubts must be cast upon critical interpretations which deem it necessary to place the poem within this genre. It must also be said, however, that Frischer's first criterion, namely that verse epistles should be 'informal in spirit', is perhaps less useful, less

15 'In books of sermones, on the one hand, he wishes to be understood as if he were talking to a person in his presence, but, on the other hand, epistulae are to be understood as if they were sent to absent people'.

16 'They [the verse letters] convey information and / or greetings (Epist. 1.1, 2, 8, 10, 16), request information or news (Epist. 1.3, 4, 11, 15), issue an invitation (Epist. 1.5), moralize (Epist. 1.6, 12, 14, 17, 18), seek foregiveness (Epist. 1.7), or commend one friend to another (Epist. 1.9)' (Frischer 1991:92-93)

17 The best indication of this can be found in the mood and tense of the verbs of the Ars, which frequently convey commands directly to the addresees as though they are in the company of the speaker. So, for example, the second person imperative is used in the following lines: $6,38,39,119$ (the imperatives here serve as headings to introduce a longer instructive passage), 141 (in a quotation), 153, 155 (in a quotation), 269, 292, $368,369,438$ (in a quotation), 459 (in a quotation).

18 pater et iuvenes patre digni (Hor. A.P. 24)

199.46 times, rounded off, by my calculations.

20 Arithmetic mean. 
facile to distinguish in a writer such as Horace who is almost always conversational in his discourse, never wholly formal or serious, even when he does engage in highly technical material as in the Ars (Toohey 1996:149).

As an addendum to this discussion of the genre of the 'verse letter', there has been a trend of late towards referring to the Ars poetica as a 'literary epistle', alongside the letters to Augustus and Florus: 'the recent tendency to consider Horace's poem on poetics as a 'literary epistle' points to the way in which it can be imagined in an original context: as a poem in the oeuvre of a major Augustan writer, who refined and built on a longstanding tradition of Aristotelian and later Hellenistic poetic theory' (Laird 2007:132-133). This would appear to represent an attempt to find a mean, a middle ground between the conversational verse epistle, as in Epistles I, and the didactic prose epistle, as in the letters of Epicurus, for example, as I have already outlined.

Laird's reference, however, to this movement towards perceiving the Ars as a literary epistle as being somehow 'recent' in critical studies of the poem is slightly misleading, as we find Wickham (1891) introducing the three longer Horatian epistles under the collective heading 'General introduction to the literary Epistles' (Wickham 1891:327). In his discussion of the concrete points of contiguity between the three longer epistles Wickham gives the following account: 'the comparison of the temperament which the Greeks and Romans severally brought to literature; the indication of the constitutional Roman vice of avarice as tainting literary men and spoiling their work; the complaint of audiences as inevitably lowering the standard of those who wrote for them; the vindication ... of the dignity and use of poetry; the disproportionate share given ... to drama; the special attack on Plautus; the use of Choerilus as the type of poetaster' (Wickham 1891:334-335). In short, Wickham's decision here to class these three longer works as 'literary epistles' stems essentially from their perceived shared subject matter, or 'res', of 'literature', in a very general sense.

Now I do not wish to imply that choice of subject is irrelevant to the designation of genre - epic tends to deal with heroic mythological tales, elegy with love affairs, and so forth - however, as the sole rubric for the inclusion of the Ars within this genre it appears feeble to me. What of the formal differences, as Frischer espouses, in the ways in which the addressees are treated in the three epistles? The absent addressee as compared to the present addressee? And what of the frequent technical language employed in the Ars (Toohey 1996:149)? And what of its length? Even when compared to the letters to Augustus and Florus, approximately 500 lines is far more characteristic of Greek didactic poems. ${ }^{21}$

${ }^{21}$ 'It is striking that they [the Greek didactic poems] all preserve the single-book format and that their length is generally in the 500-1000vv. range' (Toohey 1996:3-4). 
Indeed, this approach towards classifying the three epistles together generically also seems to ignore the position of the Ars within the surviving manuscripts, where it is treated as a single entity, a 'liber in ipso', rather than being clumped together with the other two longer epistles. There is, lastly, a rather dangerous tendency in genre studies towards the creation of sub-genres, sub-sub-genres, etc, in the pursuit of making a work 'fit' into a category, however much it might resist. So much for the literary epistle.

Progressing onto Frischer's second possible generic solution in our quest to resolve the epistolary with the hexameter in the Ars poetica, we have the didactic poem: ${ }^{22}$ 'it is strange that the case for categorizing the Ars as a didactic poem has not, to my knowledge, been made in a serious way during this century: Lucretius' De rerum natura and Virgil's Georgics certainly show how popular and prestigious was the genre in the mid- to late first century' (Frischer 1991:90).

Before tackling how the Ars might compare to such works, I think it is necessary first to question Frischer's assumption here that the genre of the didactic poem was a well-known and 'prestigious' category of literature in the first century $\mathrm{BC}$, purely on the basis of the fact that Virgil and Lucretius had attained a degree of success for their respective individual works. In fact it cannot be said that Romans from the period of the late Republic and early Empire even acknowledged the existence of such a distinct genre: '[i]t is suggestive that we can find no word in any Latin author before Servius to refer specifically either to a didactic poem or to the didactic genre. In the introduction to his commentary on the Georgics, Servius uses the Greek word didascalice, which is also found in the fourth-century grammarian Diomedes ... Didactic poetry was not generally listed by the critics as a separate genre. On stylistic grounds it was joined with epic and treated as a subset of hexameter verse' (Dalzell 1996:19-20).

Indeed, we can turn to the Ars poetica itself for evidence of this fact, where, in the discussion of the genres, no mention, either explicitly or obliquely, is made of 'didactic poetry' as a distinct category:

res gestae regumque ducumque et tristia bella quo scribi possent numero, monstravit Homerus. versibus impariter iunctis querimonia primum, post etiam inclusa est voti sententia compos; quis tamen exiguos elegos emiserit auctor, grammatici certant et adhuc sub iudice lis est ...

$$
\text { (Hor. A.P. 73-78) }{ }^{23}
$$

\footnotetext{
22 Also referred to by some critics as 'didactic epic' on account of the metre primarily.

23 'Homer showed in what meter the deeds of kings and generals, and their stern battles could be written. The 'complaint' was first associated with unequally-joined verses, then
} 
Even if we are to include didactic poetry in the broad genre of the epic in hexameter - as Dalzell suggests with reference to a passage in Quintilian, "who in his survey of Greek and Latin authors, listed the didactic ${ }^{24}$ poets alongside writers of epic and pastoral' (Dalzell 1996:20) — it is instructive for our particular purpose in analysing the Ars poetica to see that the subject matter which the Horatian text recommends for hexameter verse - 'the deeds and gloomy conflicts of both kings and leaders' - is quite incompatible with the often highly technical subject of what we customarily regard as didactic poetry. Certainly, to employ a rather rhetorical argument here, I should say that it is most peculiar for an author, who is allegedly writing in the genre of didactic poetry, to omit the slightest mention of this in an historical overview of the literary genres, which lasts for some ten verses in the poem. We therefore need to interrogate whether Horace historically regarded the didactic poem as a distinct coherent genre, and why, if he had in fact acknowledged it as a genre, he failed to give it the slightest mention in a part of his poem where its presence was demanded.

Dalzell, however, in The criticism of didactic poetry, argues against the need for a genre to be explicitly recognized by an author in order for that particular author to follow in a certain generic tradition of writers: 'It does not follow that because theory was so slow to define the status of didactic poetry, poets did not recognize that they were working in a genre which had a tradition of its own. There were literary codes which marked the distinctness of the genre. The most obvious of these was to appeal to the authority of Hesiod, the prôtos heuretês of the genre. Aratus is praised by Callimachus for following the theme and manner of Hesiod ... Virgil describes the Georgics as 'Ascraean song' (2.176) ... it was a common practice among Latin poets to indicate their literary affiliations at the beginning of their work with a graceful nod to their predecessors ... These references suggest an apostolic succession of didactic poets who are aware of their common generic links and who see themselves as carrying on a tradition which goes back to Hesiod' (Dalzell 1996:21-22).

Now to allow literary critics the freedom to ignore entirely the validity of theory ${ }^{25}$ and to define the genre of didactic poetry loosely in terms of certain 'literary codes' which may be found in a tradition of Greek and Roman writers stemming all the way back from Hesiod, as Dalzell suggests, is and has in fact proven to be a dangerous license. Just what might these literary codes be? How

afterwards amatory poetry was also included in these measures; what writer, however, first sent forth these little elegiac verses is debated by grammarians, and up till now the case is pending before a judge'. For further discussion of the problematic phrase, implying love poetry, 'voti sententia compos', see Clark 1983:1-5.

${ }^{24}$ This is a slightly misleading adjective: rather, writers whom we moderns call 'didactic'.

25 Or here its somewhat conspicuous absence. 
specific or broad should the criteria be made into which didactic poetry falls? And, since there is no ancient theory for the definite placement of this genre, under whose critical authority do we ultimately rest? Thus we can view Katharina Volk, in her approach of compiling criteria through the 'empirical evidence' of certain pre-selected poems (a sort of common-sense method), providing us with four restrictions for didactic poetry: namely, that it must have 'explicit didactic intent', a 'teacher-student constellation', 'poetic self-consciousness', and 'poetic simultaneity' (Volk 2002:36-39). Under this rubric, the Ars poetica fails to survive under the heading of didactic poetry: '[t]hus, Horace's Ars poetica, while clearly exhibiting didactic intent as well as the typical teacher-student constellation (the speaker v. the Pisones), does not show poetic self-consciousness (and therefore not poetic simultaneity either)' (Volk 2002:42). While, on the other hand, Peter Toohey, who provides the somewhat more liberal classificatory criteria of 'a strong, singular, and persuasive voice', 'striking, even sensational subject matter', 'marked variety in narrative, textual, generic, even discursive type', 'conceptual simplicity', and 'a tension between play and instruction' duly allows for the Ars poetica under this genre' (Toohey 1996:15).

One gets the impression that these criteria, without any coherent theory backing them up, have been tendentiously construed by these critics in order to match their pre-determined selections. Ironically enough, both of these commentators, in order to incorporate Ovid's elegiac Ars amatoria into their classification of 'didactic poetry', have ignored the basic criterion of hexameter verse, if we are to assume that the ancients would have placed didactic poetry within the general class of epic (as Toohey argues). Certainly, it is apparent from the passage cited in the Ars poetica that the ancient conception of genre rested more in the simple matter of metre than such abstract conceptual criteria as "poetic simultaneity' or 'a tension between play and instruction'. One must question therefore whether a Roman critic of the late Republic, or even a lay reader, would have been willing to list poems written in dactylic hexameter and elegiac couplets under the same generic class. The necessity, moreover, to incorporate such diverse works as those of Lucretius' De rerum natura, Virgil's Georgics, Ovid's Ars amatoria and even Horace's Ars poetica (with respect to subject, tone of voice, scale of treatment, and so forth) into the category of didactic poetry has in turn encouraged literary theorists, such as Bernd Effe, to provide a detailed taxonomy of didactic poetry, that is to say, further sub-divisions, as cited in Dalzell (1996:31-34). Sub-divisions of a sub-genre, which itself is not explicitly identified in any theoretical text during the historical period in question? To the aporetic reader the divisions appear endless, the solutions quite subjective.

Now, although it is rather difficult for us to consider the place of the Ars within such a malleable loose 'genre', let us briefly consider some manifest ways 
in which the Horatian poem in a most general sense might conform to, or depart from, other works of Latin literature which are commonly placed by modern critics in the tradition of 'didactic poetry', such as the De rerum natura of Lucretius, and the Georgics of Virgil.

There are perhaps two principal attractions in labelling the Ars a didactic poem: the generalizing manner in which the addressees of the poem are treated, and obviously the highly instructive and technical flavour which the work attains on occasion. On the first point, just like 'Lucretius' Memmius, whose relevance to the De rerum natura is quite problematic' (Frischer 1991:96), the identity of the Pisones does not seem relevant to the composition of the Ars; rather, on the contrary, their identity fluctuates according to the didactic purpose of the poem: 'they seem to be critics of poetry in vv.6 and 292; poets in v.24; one a critic (the father) and one a poet $(366-369,385-388)$; and it is even possible to see their number change from plural $(16,235,291)$ to singular $(102,119$, etc)' (Frischer 1991:96). So whereas in a verse letter, as we have seen, the identity of the addressee will shape the content of the epistle, in a didactic poem the addressee takes shape in accordance with the nature of the instructions at a particular point in the poem; there is, in short, no ostensible desire on the part of the didactic poet to characterize the addressees in a coherent manner such that the reader may build up a specific image in his mind of who this addressee ${ }^{26}$ is (Frischer 1991:96).

Toohey provides two other formal reasons why we might consider the Ars poetica to fall into the tradition of the didactic poems (or didactic epics) (Toohey 1996:150-151): firstly, the hexameter corresponds to those of Lucretius, Virgil, and others derived from Hesiod; and secondly, the length of the epistle is reflective of other Greek didactic poems. Just some comment now on these points: it seems a rather specious critical methodology that Toohey may here utilize the advent of hexameter to endorse the Ars' status as didactic epic, but elsewhere in his work incorporate Ovid's Ars amatoria under the same general heading. On the second point, I have already made the argument against the Ars poetica being considered a verse letter on account of its length; however, although its length does resemble other Greek didactic poems - Toohey provides the example of Nemesianus' Cynegetica (Toohey 1996:150, 204) — if we consider, as Dalzell implies, that didactic poets tended to build upon the efforts of their immediate generic predecessors, then Horace's Ars poetica falls substantially short of Lucretius' six books and Virgil's four, against which he would be judged by contemporary Romans. In other words, if Horace's Ars was a genuine attempt at a didactic poem, we might expect a far more extensive account of his subject,

26 Plural in the case of the Ars. 
perhaps in multiple books, in order to place it in the tradition of those who had written before him.

Moving onto specific arguments against the Ars being considered a didactic poem, over and above any problems which we might have with the genre itself, several important objections must be raised. Firstly, the Ars poetica, unlike most other didactic poems does not commence with a divine invocation (Frischer 1991:96); so the first book of Virgil's Georgics proceeds in laudatory fashion:

vos, o clarissima mundi

lumina, labentem caelo quae ducitis annum;

Liber et alma Ceres, vestro si munere tellus

chaoniam pingui glandem mutavit arista,

poculaque inventis Acheloia miscuit uvis;

et vos, agrestum praesentia numina, Fauni,

ferte simul Faunique pedem Dryadesque puellae:

munera vestra cano ...

(Virg. G. 1.5-12) ${ }^{27}$

And so the poem continues with reference to Neptune, Pan, Minerva, Silvanus, dique deaeque omnes (Virg. G. 1.21). Contrast the elevated language here - the invocation to not one but multiple gods, the superlative clarissima mundi (line 5), the anaphora of co-ordinating conjunctions to garner a sense of immense scale, the hyperbaton of the main clause verb, cano (line 12), right to the end of the sentence to leave the poet breathless — with the opening of the Ars poetica:

humano capiti cervicem pictor equinam iungere si velit et varias inducere plumas undique collatis membris ut turpiter atrum desinat in piscem mulier formosa superne, spectatum admissi risum teneatis, amici?

(Hor. A.P. 1-5) $)^{28}$

27 'You, the brightest lights of the universe, who conduct the year as it slips along the sky; Liber and bountiful Ceres, if, by your gift, the earth changed Chaonian acorns for the rich beard of grain and mixed the draughts of Achelous with the recently-found grapes; and you, Fawns, protecting divinities of the countryside - move your feet, Fawns and Dryad girls: I sing of your gifts ...'

28 'If a painter wishes to join the neck of a horse with a human head, and to place various feathers over them, with limbs assembled here and there, such that a shapely woman from above ends foully in a hideous fish, might you, my friends, restrain your laughter, once invited to a viewing'. 
While the Virgilian text soars in lofty descriptive language, the Ars is content to plunge at once into a meditation of its subject, here the unity of an artistic work, through a far more playful conversational type of discourse. Indeed, even Lucretius, whose subject, Epicurean philosophy, would rally strongly against any tangible divine intervention in his view of a materialistic world, deems it necessary to fall in line with the tradition of didactic poets by invoking the goddess Venus at the start of his first book.

Secondly, with regard to Dalzell's insistence that didactic poems should somehow reference themselves with regard to their generic predecessors, there seems to be no point in the Ars where the poem explicitly relates its own position in accordance with other didactic epics, such as those of Lucretius or Virgil (Dalzell 1996:21-22). The reference to Virgil in line 55 of the Ars pertains to the introduction of neologisms into the Latin language and the biased preference which is often given to writers of the past, such as Cato and Ennius. It has nothing to do with Virgil's Georgics or didactic epic in general. It is in fact not uncommon for other Horatian poems to account for their generic position by citing a predecessor in the field: so Satire 1.4 alludes to the tradition in which it might be placed by presenting the satirist Lucilius and the writers of Old Comedy, 'on whom he relied entirely':

Eupolis atque Cratinus Aristophanesque poetae atque alii quorum comoedia prisca virorum est, si quis erat dignus describi quod malus ac fur, quod moechus foret aut sicarius aut alioqui famosus, multa cum libertate notabant.

hinc omnis pendet Lucilius ...

(Hor. Sat. 1.4.1-6) ${ }^{29}$

In short, if the Ars poetica were designed by Horace to stand in the tradition of didactic poetry, we would expect some manifest suggestion of his place in the genre.

At the conclusion to this discussion on didactic poetry, I think it is apt to quote an observation by Brink as to the nature of the Ars poetica: 'Its addiction to technicality is greater than that of any other literary satires or epistles. On the other hand the conversational and apparently inconsequential manner equals if it does not surpass that of the other works on poetry' (Brink 1963:3). How does one

29 'Eupolis, Cratinus and Aristophanes, and the other poets who make up Old Comedy, used to depict with great freedom if there was anyone worth being portrayed on account of his being a criminal and a thief, an adulterer or a murderer - or in any other way notorious. Lucilius hangs entirely from these men'. 
resolve the technical didactic element in the Ars with the playful conversational tone? Does placing it within the genre of didactic poetry solve this difficulty? Certainly, the Ars, as we have seen, departs from the formal structure of other prestigious Latin works which we regard as didactic poems nor does it appear willing to place itself in such a distinct generic category, as witnessed in the discussion of literary genres in the poem itself. Moreover, the Ars does not give the type of systematic presentation of material which we get over the four books of Virgil's Georgics or the six of Lucretius' De rerum natura; the argument of the Ars is far more free-flowing and conversational - 'it does not follow', to get to the etymological root of Brink's descriptive adjective 'inconsequential', the typically logical structure which we might expect in a more technical account.

If we find ourselves, like Peter Toohey, radically re-adjusting our criteria of what we consider to be 'didactic poetry', with all too liberal, quite subjective, categories such as 'striking, even sensational subject matter', 'marked variety in narrative, textual, generic, even discursive type' or 'a tension between play and instruction', in order to fit a seemingly irresolvable work into a specific classification, we might find that the genre itself becomes so conceptually inclusive of a wide range of works so as to be critically useless.

Finally, moving onto Frischer's third possible solution to the genre of the Ars poetica we have his tertium quid, the sermo (Frischer 1991:96-97). For Frischer the sermo is not so much a distinct literary category which can be identified in a tradition of writers preceding Horace but rather a characteristically Horatian creation, a Kreuzung der Gattungen, a deliberate mixing of conventions from different traditions: 'lest the suggestion that the Ars poetica be classified as exemplifying the mixed genre of sermo - an Aufhebung of the simple forms of technical handbook, didactic poem, and letter-seem strange or unlikely, it may be well to point out that such portmanteau arrangements of genres within genres have been encountered in other periods and literatures (Frischer 1991:99); apart from such an historical precedent, Frischer provides further justification for this labelling of the Ars as a sermo by referencing a passage in the first book of epistles wherein 'Horace claims that his achievement was due to his originality ${ }^{30}$ in mixing generic characteristics' (Frischer 1991:99):

libera per vacuum posui vestigia princeps, non aliena meo pressi pede. qui sibi fidet dux reget examen. Parios ego primus iambos ostendi Latio, numeros animosque secutus Archilochi, non res et agentia verba Lycamben.

30 My emphasis. 
ac ne me foliis ideo brevioribus ornes

quod timui mutare modos et carminis artem:

temperat Archilochi Musam pede mascula Sappho,

temperat Alcaeus, sed rebus et ordine dispar ...

(Hor. Epist. 1.19.21-29) $)^{31}$

Frischer's ultimate interpretation of the Ars Poetica, as lying within the "new genre' of the sermo leads us onto the primary theoretical point of debate in all genre studies, that is the polarity which exists between the traditional and the original in a given work. If we are studying a work entirely by genre, relating an artist's production to those who have preceded him, we risk neglecting the extent to which the work is an original creation, its 'essential uniqueness' (Dalzell 1996:3) - a concern which has led post-modern criticisms, committed to the irresolvable nature of the text, largely to reject the efficacy of literary genres (Dalzell 1996:4); on the other hand, from a practical point of view, genres, in giving points of contiguity - literary codes - between individual works, do 'provide the critic with a strategy for dealing with texts' (Dalzell 1996:6). However, as I have mentioned previously with regard to didactic poetry, when the criteria or codes of a generic category become too inclusive, they risk losing their utility for the critic. Frischer's allowance for the Horatian sermo to include, in different proportions, elements of three root genres (technical handbook, didactic poem, and verse epistle), means that we have poems as diverse as the Priapean Satire (Satire 1.8) and the Ars poetica under the same generic title of sermo in his system of categorization (Frischer 1991:98). Of what critical utility is a classification which incorporates such manifestly different poems? What is the basis of similarity?

Furthermore, if 'Horace' ${ }^{32}$ is understood to be constantly emphasising the essential primacy, the novelty of his work - princeps (line 21), primus (line 23) as in Epistle 1.19 - and since, with particular regard to the Ars poetica, he is not overtly concerned with placing his own work inside a specific tradition of writers, we must then question the validity of analysis by genre. Indeed, Dalzell points out

31 'I was the first to place my footsteps freely over the empty earth, nor did my feet press over the tracks made by others. He, who has faith in himself, rules the common herd, a leader. Indeed, I was the first to show Latium the Parian iambics, having followed the rhythm and the spirit of Archilochus, but not his subject matter and his words (which hunted down Lycambes). And do not, therefore, adorn me with smaller wreaths, because I was afraid to alter the measures and artistic design of the song: manly Sappho tempers her muse through the metre of Archilochus; Alcaeus likewise, but differs in his subjects and arrangement ...'

32 Again the inverted commas distinguish between the authorial persona and the historical personage. 
that in modern literary studies analysis by genre has become especially troublesome on account of writers who are committed 'to shatter the very idea of genre' (Dalzell 1996:4), far removed from the 'obliging' authors of antiquity. And yet this 'shattering of genre' is just what 'Horace' confesses to in Epistle 1.19. In short, when we judge whether the Ars poetica displays coherence, we should firstly, before applying the standards of other literature, attempt to analyse it in ipso - as far as is realistically possible. Once we have acknowledged the form of the Ars by itself, we may accordingly draw comparisons with other works.

\section{BIBLIOGRAPHY}

Anderson, W S 1982a. Roman satirists and literary criticism. In Essays on Roman Satire. Edited by W S Anderson. Princeton: Princeton University Press. 3-10.

Anderson, W S 1982b. The Roman Socrates: Horace and his satires. In Essays on Roman Satire. Edited by W S Anderson. Princeton: Princeton University Press. 13-49.

Anderson, W S 1982c. Autobiography and art in Horace. In Essays on Roman

Satire. Edited by W S Anderson. Princeton: Princeton University Press. 50-73.

Armstrong, D 1989. Horace. New Haven: Yale University Press.

Armstrong, D 1993. The addressees of the Ars poetica: Herculaneum, the Pisones and Epicurean protreptic. $M D$ 31:185-230.

Brink, C O 1963. Horace on poetry: Prolegomena to the literary epistles. Cambridge: Cambridge University Press.

Brink, C O 1971. Horace on poetry: The Ars poetica. Cambridge: Cambridge University Press.

Brown, P M 1993. Horace: Satires 1. Warminster: Aris \& Philips.

Clarke, M E 1983. Horace, 'Ars poetica' 75-78: The origin and worth of elegy. CW 77.1: 1-5.

Dalzell, A 1996. The criticism of didactic poetry. Toronto: University of Toronto Press.

Depew, M \& Obbink D 2000. Introduction. In Matrices of genre: Authors, canons and society. M Depew and D Obbink (eds.), Cambridge, MA: Harvard University Press. 1-14.

Dilke, O A W 1958. When was the Ars poetica written? BICS. 5:49-57.

Duckworth, G E 1965. Horace's hexameters and the date of the Ars poetica. TAPA 96:73-95.

Effe, B 1977. Dichtung und Lehre: Untersuchungen zur Typologie des antiken Lehrgedichts. Munich: C H Beck'sche Verlagsbuchhandlung. 
Ferri, R 2007. The Epistles. In The Cambridge companion to Horace. Edited by S Harrison. Cambridge: Cambridge University Press. 121-131.

Fowler, D 2000. The didactic plot. In Matrices of genre: Authors, canons and society. M Depew and D Obbink (eds.), Cambridge, MA: Harvard University Press. 205-219.

Frischer, B 1991. Shifting paradigms: New approaches to Horace's Ars poetica. Atlanta: Scholars Press.

Gildersleeve, B L \& Lodge, G 1903. Latin Grammar. London: Macmillan and Co.

Harrison, S 1995. Some twentieth-century views of Horace. In Homage to Horace. Edited by S Harrison. Oxford: Clarendon Press. 1-16.

Harrison, S 2007. Horatian self-representations. In The Cambridge companion to Horace. Edited by S Harrison. Cambridge: Cambridge University Press. 22-35.

Hornblower, S \& Spawforth, A (eds.), 1996. The Oxford Classical Dictionary. Oxford: Oxford University Press.

Kennedy, G A 1992. Is Horace's Ars poetica a parody? AJPhil 113.3: 441-442.

Laird, A 2007. The Ars poetica. In The Cambridge companion to Horace. Edited by S Harrison. Cambridge: Cambridge University Press. 132-143.

Miller, J F 1993. Apostrophe, aside and the didactic addressee: Poetic strategies in Ars amatoria III. MD 31:231-241.

Mitsis, P 1993. Committing philosophy on the reader: Didactic coercion and reader autonomy in the De rerum natura. MD 31:111-128.

Oxford Latin Dictionary 1968-1982. Oxford: London Clarendon.

Palmer, A 1968. The satires of Horace. London: Macmillan.

Plotnick, J 1979. Horace on satyr drama. CW 72.6: 329-335.

Regel, G 1836. Index verborum: Horatius. ${ }^{33}$

Roggen, V 2008. The effects of genre on the value of words: 'Didactic poetry versus satire'. $C Q$ 58:547-564.

Rudd, N 1960. Horace on the origins of satura. Phoenix 14:36-44.

Rudd, N 1989. Horace: Epistles Book II and the epistle to the Pisones. Cambridge: Cambridge University Press.

Russell, D A 1973a. Ars poetica. In Horace. Edited by C Costa. London: Routledge. 113-134.

Smith, W K 1936. The date of the Ars poetica. CPhil 31.2: 163-166.

Syme, R 1980. The sons of Piso the pontifex. AJPhil 101.3: 333-341.

Tarrant, R 2007. Ancient receptions of Horace. In The Cambridge companion to Horace. Edited by S Harrison. Cambridge: Cambridge University Press. 277-290.

33 No information regarding location and publisher given. 
Toohey, P 1996. Epic lessons: An introduction to ancient didactic poetry. London: Routledge.

Volk, K 2002. The poetics of Latin didactic. Oxford: Oxford University Press.

Wickham, E C 1891. The works of Horace, Vol. II. Oxford: Clarendon Press.

Wilkins, A S 1886. The Epistles of Horace. London: Macmillan and Co.

Wimsatt, W K \& Beardsley, M C 1972a. The intentional fallacy. In $20^{\text {th }}$ Century Literary Criticism. Edited by D Lodge. London: Longman. 334-344.

Wimsatt, W K \& Beardsley, M C 1972b. The affective fallacy. In $20^{\text {th }}$ Century Literary Criticism. Edited by D Lodge. London: Longman. 345-358.

Wiseman, T P 1988. Satyrs in Rome? The background to Horace's Ars poetica. JRS 78:1-13. 